\title{
Foreword: After Afrofuturism
}

\section{GEORGE E. LEWIS}

Welcome to our special issue on Technology and Black Music in the Americas. As guest editor, I'd like to offer my personal thanks to all of our contributors, who are exploring relatively uncharted currents in the overall flow of black music technology. I'd also like to thank JSAM editor Ellie M. Hisama and assistant editor Benjamin Piekut for their tireless efforts, as well as their extraordinary abilities as editors to navigate quickly between leaf- and forest-level views.

This issue has proved resolutely intergenre, as literary scholars, visual artists, and academically trained practicing artists jostle musicologists and ethnomusicologists. My extended foreword will not summarize the themes addressed by the articles. Instead, I wanted to think for a moment about the strange fact that despite our explicit call for papers addressing intersections of music, race, gender, technology, science fiction, diaspora, utopia, Afrofuturism, and posthumanism, the widely referenced term "Afrofuturism" rarely appears in the articles and reviews in this issue.

Thus I feel constrained to present (or "represent") some issues in this area. My remarks are not intended to position me as respondent, although I do incorporate quotations from the authors represented. Rather, like John Cage, who used parts of older works to construct new performances, this foreword demonstrates the intent of my guest editorship through a collaging of insights drawn from the authors published here with the various hobbyhorses I've been riding for a number of years now. Along the way, since this issue is meant to encourage scholarship rather than provide a compendium of the present, I couldn't resist offering some suggestions for areas of future research.

Mark Dery coined the term "Afro-futurism" in a 1994 set of interviews with Tricia Rose, Samuel R. Delany, and Greg Tate. The discussions were largely concerned not with music, the topic we are vitally interested in here, but with the relative absence of black science fiction writers. ${ }^{1}$ In the introduction to the interviews, a largely prosthetic technological imaginary dominated Dery's references to writing and sound-Jimi Hendrix, Herbie Hancock, Sun Ra, Lee "Scratch" Perry, and the Parliament/Funkadelic combine, represented by George Clinton and Bernie Worrell. ${ }^{2}$ This seemed to indicate that even if the original intent of the proponents of Afrofuturism included the recognition that "African American voices have other

\footnotetext{
${ }^{1}$ Mark Dery, "Black to the Future: Interviews with Samuel R. Delany, Greg Tate, and Tricia Rose," in Flame Wars: The Discourse of Cyberculture, ed. Mark Dery, 179-222 (Durham, N.C.: Duke University Press, 1994).

2 I'm using the term "prosthetic" in contradistinction to my notion of the incarnative; the opposition is developed in Doris Lessing's space novels, which contrast the body politics of the machine-making Sirians with those of the spiritual technologies of the Canopeans. See Doris Lessing, The Sirian Experiments: The Report by Ambien II, of the Five (New York: Vintage Books, 1982).
} 
stories to tell about culture, technology and things to come," 3 the working out of these voices in an actual art world-what cybertheorist Alondra Nelson called the "concerns of 'the list'" of artists and writers who later cofounded the Afrofuturism listserv and website, as well as the canon of Afrofuturist music-was essentially bound up, at least in its initial incarnation, with "sci-fi imagery, futurist themes, and technological innovation in the African diaspora."4

A contrasting, Caribbean-originated vision of the relation between blackness and technology appears in Aimé Césaire's classic 1939 work, Cahier d'un retour au pays natal (Notebook of a Return to the Native Land), which appears to ground the purity of black subjectivity in technological lack:

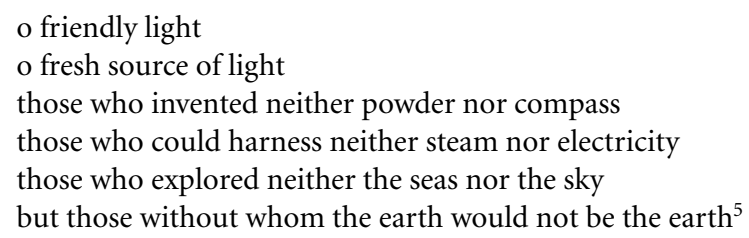

On the other hand, Michael Veal, whose book on the histories and practices of dub is reviewed by Louis Chude-Sokei in this issue, maintains that in the late twentieth century, "Jamaican attitudes toward technology actually contradict these oppositional distinctions between a past understood as nature-based, primitive, and stereotypically African, and a future understood as technological and stereotypically de-Africanized." ${ }^{6}$ Where critic Abiola Irele contends that Césaire's passage uses the supposed technical nonproficiency of African civilizations as support for a "vibrant affirmation of racial pride," one can easily imagine the passage sticking in the craw of the Afrocentric hero Cheikh Anta Diop, who with many others contended that the highly technologized Egyptian (pre-Ptolemaic) civilization was one with Afro-diasporic cultures around the world.

In the post-Sun Ra Chicago of the 1970s (Sun Ra himself being "post-J. A. Rogers" and other independent black researchers of the 1920s through the 1940s), it was taken for granted by young African Americans of my generation that the "Cultural Unity of Black Africa" (to reference one of Diop's works) bundled ancient Egypt with the South Side of Second City. ${ }^{8}$ The pyramids, of course, were one of the seven wonders of the ancient world, but even among the most ardent Afrocentrists or their equally implacable opponents, few had heard of Philip Emeagwali or Roscoe

${ }^{3}$ Dery, "Black to the Future," 182.

${ }^{4}$ Alondra Nelson, "Introduction: Future Texts," Social Text 20/2 (Summer 2002): 9. Nelson is founder of the Afrofuturism listserv and website (http://groups.yahoo.com/group/afrofuturism and http://www.afrofuturism.net).

${ }^{5}$ Aimé Césaire, Notebook of a Return to the Native Land, trans. and ed. Clayton Eshleman and Annette Smith (Middletown, Conn.: Wesleyan University Press, [1939] 2001), 34.

${ }^{6}$ Michael E. Veal, Dub: Soundscapes \& Shattered Songs in Jamaican Reggae (Middletown, Conn.: Wesleyan University Press, 2007), 213-14.

${ }^{7}$ Aimé Césaire, Cahier d'un retour au pays natal, 2nd edn., with introduction, commentary, and notes by Abiola Irele (Columbus: Ohio State University Press, [1939] 2000), 117.

${ }^{8}$ Cheikh Anta Diop, The Cultural Unity of Black Africa: The Domains of Patriarchy and of Matriarchy in Classical Antiquity (Chicago: Third World Press, 1978). 
Giles, who were inventing the internet backbone and developing supercomputers around the same moment that the rather more modest nineteenth- and early twentieth-century achievements of Jan Matzeliger and Garrett Morgan were being marketed as "positive images" to young twentieth-century African Americans in search of evidence of black technological prowess. ${ }^{9}$

George Lipsitz's review here of Alexander Weheliye's Phonographies cites Weheliye's understanding that "thinking about sound is essential for sound thinking." At the same time, as Lipsitz gently prods Weheliye to interrogate the division between sight and sound, one can imagine asking music/sound scholars to take up the challenge of achieving intertextuality by first developing new ways of theorizing sound. What does the sound-not dress, visual iconography, witty enigmas, or suggestive song titles-what can the sound tell us about the Afrofuture? How can we develop a new theoretical and descriptive language that both complements and exceeds the purview of the terms "music," "sound," and "listening"?

French economist Jacques Attali, in his 1977 book Bruits—a futurist text to be sure-provided a fair amount for musicologists to ponder, not least by repurposing the term "composition" in a manner that recalls improvisation. One sees Attali as responding to the marginalization and devaluation, in the public sphere, of the practice of culturally and philosophically theorizing contemporary nonliterary, nonvisual sonic "texts" (a term used here for lack of a more developed sonic discursivity)—not because music scholars are not producing the work, but perhaps because it has somehow gone without saying that music has little to teach us about the critical issues of our time. In deploying music as a critical tool for analyzing contemporary critical, cultural, historical, and social issues whose importance cuts across fields, it is not interdisciplinarity or intertextuality that matter as much as the kinds of interpretational catholicity and trenchancy enabled by the two approaches.

Again, what we really want to know is if music has anything to tell us about the future, and if the confluence of music with technology will teach us anything about ourselves.

Jann Pasler, for example, draws important theoretical insights from compositional methodologies such as those of Pauline Oliveros and Cage, lending credence to the notion of the intrinsic centrality of music study to intellectual inquiry and human experience. ${ }^{10}$ Lipsitz makes the case for the centrality of music to the public sphere in his review: "Afro-sonic modernity has been where the liberal citizen subject meets the cyborg, where technology intersects with art, where commerce and culture collide, and where memories of ancestors pervade contacts with strangers. Weheliye makes a persuasive case that there would be no modernity without blackness and its many representations."

\footnotetext{
${ }^{9}$ For a representative US mainstream media account of the "Afrocentric education" controversy of the 1990s, see Barbara Kantrowitz et al., "A is for Ashanti, B is for Black," Newsweek, 23 September 1991.

${ }^{10}$ Jann Pasler's methodology is on fuller display in her recent book, Writing Through Music: Essays on Music, Culture, and Politics (New York: Oxford University Press, 2008).
} 
This viewpoint, of course, is diametrically opposed to Norman Mailer's 1973 prediction that "[s]ince the Negro has never been able to absorb a technological culture with success, even reacting against it with instinctive pain and distrust, he is now in this oncoming epoch of automation going to be removed from the technological society anyway."

Michael Veal's book on dub asks us to consider "whether Afro-futurism is fundamentally an African American trope, reflecting a particular proximity to the cold war. Much of the emphasis on technology seems a likely reflection of the space race as a component of the arms race...." Veal further observes that dub itself "tends to be less concerned with images of flying saucers and interplanetary travel, and is more reflective of prominently interwoven dichotomies of nature/technology and past/future." 13 Thus, although this issue was originally projected as "the Afrofuturism issue," considering the implications of Veal's remark leads us to understand that the science-fiction model could only account for a fraction of contemporary Afrodiasporic imaginings of technology. In the course of my editor's task it was becoming evident that Afrodiasporic people were asserting non-Afrofuturist engagements with technology. It was this larger world that intrigued me, where resistance was by no means futile. For instance, one can easily view Santería as a kind of technology designed to facilitate communication with higher powers and condition the neo-Yoruban Afrofuture. As with the more usually invoked siliconbased machines of today, the example of Santería shows us that we need not eschew the spiritual dimensions of black engagement with technology.

Broadening the conversation would allow a wider range of theorizing about the triad of blackness, sound, and technology; for a start, one could interrupt the maleness of the Afrofuturist music canon with artists such as Pamela Z, DJ Mutamassik, Mendi Obadike, Shirley Scott, Dorothy Donegan, the Minnie Riperton/Charles Stepney/Rotary Connection collaborations, and more. Going further, removing the putative proscription on nonpopular music allows us to take a more nuanced, complex view of the choices on offer for black technological engagement, as artist Morgan Craft (whose work with Mutamassik is reviewed in this issue) noted in an impassioned letter to the British music magazine The Wire:

As far as hiphop being the future, well, the things Ornette Coleman, Butch Morris, Cecil Taylor, Braxton, etc talk about are not the same things that rappers or producers are talking about (exception: RZA five years ago). I'm listening and I want to eat these words. What does the black American musician do now with the space s/he has been given? ${ }^{14}$

Indeed, this is an important question for young black musicians choosing alternative nodes in the network. In the course of their navigation, some of these young people might encounter the now eighty-seven-year-old Egyptian Halim El-Dabh, who was experimenting in a radio studio in Cairo a half-decade before the advent of

${ }^{11}$ Quoted in Michele Wallace, Black Macho and the Myth of the Superwoman (London: Verso, [1978] 1999), 46. Also see Norman Mailer, Existential Errands (New York: New American Library, 1973).

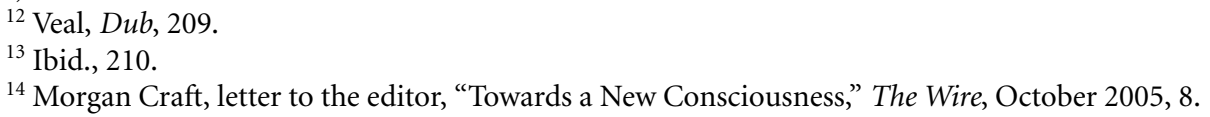


musique concrète..$^{15}$ El-Dabh, who worked in the Columbia-Princeton Electronic Music Studios in the 1950s, was recognized as the "father of African electronic music" at the 2005 UNYAZI Electronic Music Festival in Johannesburg, the first event of its kind on the mother continent.

Along those lines, scholars might want to pay more attention to the work of Anthony Davis, particularly his second opera, a space-fiction drama called Under the Double Moon (1989), with a libretto by Deborah Atherton about telepathic miscegenation on the mythical planet Undine. The work raises the issue of whether the realities of operatic reception in the West could ever be subsumed under the narrative of radical, populist, post-agrarian high art. Truth be told, however, that landscape vanished a long time ago, along with the American frontier myth that nurtured it-hip-hop, currently riven with harsh debates over commercialism and political retrogression, having failed (and serendipitously so) as perhaps the last viable candidate for the purple, as symbolized by Jay-Z's 2003 celebration of capitalism on the CBS television news review, 60 Minutes.

Further broadening also allows us to consider, as does Ajay Heble's review here of Herman Gray's book Cultural Moves, that "encounters between such technologies and black vernacular musical practices have resulted in new understandings of blackness, identification, and belonging through sound," leading to the possibility, strongly cherished by Heble, of promulgating "progressive projects for social justice." At the same time, this forces the realization that there is much, much more to be done-much of it, unfortunately, in the same mode of recovery that one finds so depressing, although necessary.

This décalage exists for many reasons, which of course cannot be reduced to questions of race. In any case, these reclamation projects, which I enjoy even as some younger people find them tedious and vindicationist, proceed from the noble motive of writing back into history some of those whom mainstream histories have written out - in particular, those whose work went beyond the bounds of popular taste, or at least beyond the tastes of those commentators who are busy creating newer forms of the same gatekeeping narratives surrounding black expression. Certainly, technology is one of those areas of the African diaspora where these projects of reclamation are most sorely needed, and what I want to suggest is that these histories of technology are discontinuous, local, and heedless of simplistic racializations.

Finally, taking up Veal's challenge to move beyond the dominance of African American cultural and historical tropes allows the technologies of the Afrofuture to be imagined globally, as with the series of "AfroGEEKs" conferences organized by film scholar Anna Everett. These conferences featured critiques of technologically mediated representations of black masculinity, studies of video game culture, confrontations with the "digital divides" that condition black access to digital

\footnotetext{
${ }^{15}$ Hear, for example, his 1944 "Wire Recorder Piece." See Halim El-Dabh, Crossing Into the Electric Magnetic, Without Fear Recordings WFR003, 2000. A fascinating biography of this widely traveled Egyptian composer and ethnomusicologist, which includes a compact disc of previously unreleased works, is Denise E. Seachrist, The Musical World of Halim El-Dabh (Kent, Ohio: Kent State University Press, 2003).
} 
technology in Africa and its diaspora, and issues of globalization and economic modernization in Africa and the Caribbean. ${ }^{16}$

The Afrofuturist encounter produced an extraordinary 1999 conference, ${ }^{17}$ a lively listserv and website, ${ }^{18}$ and like its Italian cousin, a fair number of manifestos, of which the classic 1998 disquisition of Kodwo Eshun, More Brilliant Than the Sun: Adventures in Sonic Fiction, might be considered the most extended and influential. ${ }^{19}$ It was in this work that Eshun coined the extraordinarily powerful term "sonic fiction." As Eshun made clear in an interview with cybertheorist Geert Lovink, this work constituted a response to the need for a kind of extra-academic activism in new media: "I realized that there are several people with a similar structural position, who had left academia, infiltrating pop cultural spaces. They did not footnote their work and refused to contextualize their work. I wasn't alone. There were sectors in every city who were moving along similar tendencies."20

Alexander Weheliye, who still footnotes his work, has commented:

According to Eshun, black posthumanism stands in stark contrast to the strong humanist strand found in a host of black cultural styles, ranging from the majority of African American literature to the history of soul and the blues. Eshun describes these two modes of thinking as Afro-diasporic futurism and the humanist future—shock absorbers of mainstream black culture. Eshun's important work unearths some of the radical strands of black music that refuse to uncritically embrace the Western conception of "the human," are largely instrumental, and therefore do not rely on the black voice as a figure of value. ${ }^{21}$

At the same time, Weheliye points out:

From nineteenth-century spirituals through the blues, jazz, soul, hip hop, and techno, the human and the posthuman are in constant dynamic tension. It is precisely because slavery

16 The AfroGEEKS 2004 and 2005 conference website, "From Technophobia to Technophilia" and "Global Blackness and the Digital Public Sphere," is at http://research.ucsb.edu/cbs/projects/ afrogeeks.html. A recently edited volume derived from the concerns of these conferences is AfroGEEKS: Beyond the Digital Divide, ed. Anna Everett and Amber J. Wallace (Santa Barbara, Calif.: Center for Black Studies Research, 2007).

${ }^{17}$ Alondra Nelson organized "Afrofuturism Forum" at New York University in 1999. The interdisciplinary set of participants included Beth Coleman, Kodwo Eshun, Leah Gilliam, Jennie C. Jones, Kobena Mercer, Tracie Morris, Erika Dalya Muhammad, Simon Reynolds, Tricia Rose, and Reginald Woolery. See Nelson, "Introduction: Future Texts," 15 n. 25.

${ }^{18}$ The Afrofuturism website is at http://www.afrofuturism.net/. Among the various manifestos that dot its pages are Paul D. Miller, "Afro-Futurism: A Statement of IntentionsOutside In, Inside Out," 2002, http://www.afrofuturism.net/text/Manifestos/Miller01.html. Another intriguing manifesto is Mark A. Rockeymoore, "What Is Afrofuturism?" AuthorsDen website, http://www.authorsden.com/visit/viewarticle.asp?AuthorID=7174\&id=4308.

${ }^{19}$ See Kodwo Eshun, More Brilliant Than the Sun: Adventures in Sonic Fiction (London: Quartet Books, 1998). So far this important book remains out of print (as of January 2008, used copies on Amazon.com are offered from US\$81 to \$345), recalling the absence from the marketplace of the important early Arista recordings of Anthony Braxton (among many others, particularly in jazzidentified worlds), currently offered at Amazon from US\$40 to \$99. Many musicians suspect that the companies, which in most cases own the rights to the work, choose cynically to wait until the creator's death to capitalize; an even less charitable, more conspiratorial version sees it as the simple suppression of inconvenient ideas.

${ }^{20}$ Geert Lovink, "'Everything was to be done. All the adventures are still there': A Speculative Dialogue with Kodwo Eshun," 2000, Telepolis website, http://www.heise.de/tp/r4/artikel/6/6902/1.html.

${ }^{21}$ Alexander G. Weheliye, "Feenin': Posthuman Voices In Contemporary Black Popular Music," Social Text 20/2 (Summer 2002): 29. 
rendered the category of the human suspect that the reputedly humanist postslavery black cultural productions cannot and do not attribute the same meaning to humanity as white American discourses. ${ }^{22}$

Nelson's connection of Afrofuturism with its 1920s Italian predecessor is an entirely natural move; ${ }^{23}$ moreover, any futurism worth its salt should properly be tempted to claim a certain prescience, preferably with the same sense of evangelical ecstasy that permeates Eshun's book. This imputation of the oracular is routinely madewith a similar fervor and often with a certain insouciance regarding timelines-for Sun Ra's work, and as for jazz more generally, particularly in the post-Marsalis era, with death the legend only grows.

Ra's use of electronics is a crucial component of the claim to "pre-science" (a metanalysis that Ra might have enjoyed). Yet no academic treatise of which I am aware has historically traced and contextualized Ra's use of sound technologies—or for that matter, that of the composer George Russell, one of the US pioneers in pan-African collaborations who used "space" titles in his work (Jazz in the Space Age, 1960) and whose 1968 Electronic Sonata for Souls Loved By Nature, realized in the studios of Swedish Radio with musicians such as future "Nordic jazz" founder Jan Garbarek, combine electronic tape collages with improvisation. ${ }^{24}$ While we're at it, one area that might prove fruitful is the tracing of the technological histories of two other African American musicians who have flown well under the Afrofuturist radar: Olly Wilson, the composer and founder of the Oberlin Electronic Music Studio, and David Levitt, former MIT researcher working on computer models of music making, and the author of HookUp, an early visual patching language that was developed and running among Levitt's students at the Media Lab while Miller Puckette, the author of the now dominant patch language, Max/MSP, was a graduate student there. ${ }^{25}$

${ }^{22}$ Ibid., 30.

${ }^{23}$ Nelson, "Introduction: Future Texts," 2.

${ }^{24}$ I'm indebted to Harald Kisiedu for this reminder. One of the few substantial accounts of Russell's Electronic Sonata is contained in Max Harrison, Charles Fox, and Eric Thacker, The Essential Jazz Records, vol. 2, Modernism to Postmodernism (London: Continuum International Publishing Group, 2000), 242-44. For a reference to Russell's contribution to the early collaborations with conguero Chano Pozo, see Jason Stanyek, "Transmissions of an Interculture: Pan-African Jazz and Intercultural Improvisation," in The Other Side of Nowhere: Jazz, Improvisation, and Communities in Dialogue, ed. Daniel Fischlin and Ajay Heble, 87-130 (Middletown, Conn.: Wesleyan University Press, 2004).

${ }^{25}$ For an early report on HookUp, see Christopher Yavelow, "A Report on the Workshop for Music Notation by Computer," Computer Music Journal 11/2 (Summer 1987): 65-70. For a photo of the HookUp user interface, see "Product Announcements," Computer Music Journal 14/2 (Summer 1990): 90. David A. Levitt's influential compendium of work on computer music modeling, coedited with Stephan M. Schwanauer, is Machine Models of Music (Cambridge: MIT Press, 1993). In his account of the origins of the Max visual patcher interface, Miller Puckette, its developer, doesn't mention HookUp, perhaps the most proximate immediate precursor in terms of look and feel. Puckette observed: "Many other graphical patch languages—-both for music and for other applications — had appeared by 1987 when I started writing the Max 'patching' GUI [graphical user interface]. Although several specific elements might have been novel, at least in the computer music context, the overall idea of a graphical patch language was not." See Miller Puckette, "Languages and Environments for Computer Music: Max at Seventeen," Computer Music Journal 26/4 (Winter 2002): 33. 
Finally, opening up the network allows us to harmonize with the sense in which tropes of techne are deployed in Mike Heffley's essay on Anthony Braxton-in this case, by engaging the thought of Kali Tal, whom Nelson cites as suggesting that "over a century's worth of 'sophisticated tools for the analysis of cyberculture' already existed in African American thought." ${ }^{26}$ Chela Sandoval raises the historical ante still further, with her assertion that the brunt of cyborg life in the twenty-first century is borne not nearly as much by artists as by

the muscles and sinews of workers who grow tired in the required repetitions, in the
warehouses, assembly lines, administrative cells, and computer networks that run the great
electronic firms of the twentieth century. These workers know the pain of the union of
machine and bodily tissue, the robotic conditions, and in the late twentieth century, the
cyborg conditions under which the notion of human agency must take on new meanings....
Cyborg life as a worker who flips burgers, who speaks the cyborg language of McDonald's,
is a life that the workers of the future must prepare themselves for in small, everyday ways. ${ }^{27}$

Nonetheless, for Sandoval, over the last three hundred years these people and others "had already developed the Cyborg skills required for survival under techno-human conditions:"28 "la facultad," as Sandoval cites Gloria Anzaldúa's term, or reading signs; deconstruction and meta-ideologizing, aimed at the rearticulation of signs of dominance; the reassertion of egalitarian social relations; and what Sandoval calls "differential movement," a "polyform" appearing as womanism, mestizaje, or strategic essentialism - "a differential form of oppositional consciousness, as utilized and theorized by a racially diverse US coalition of women of colour, is the form love takes in the postmodern world. It generates grounds for coalition, making possible unity across difference." ${ }^{29}$

One is struck by the absence of blackness from narratives of musical postmodernity, at least where "art music" (to deploy that rather wan category) is concerned. It cannot be accidental that lacunae of this sort populate the areas of theoretical and historical music scholarship, which have found gender a far more tractable category of analysis than race. In these worlds of scholarship, race is easily seen as proper to black music studies; less immediately evident, however, is its centrality to theorizations of the historical reception and production of putatively non-black musics. Even so, as Jann Pasler has shown, ${ }^{30}$ and as Vijay Iyer notes in his review in this issue of Mark Butler's book on electronic dance music, "the very language of the discipline has come into being against the backdrop of the racial imagination."

${ }^{26}$ Nelson, "Introduction: Future Texts," 3.

${ }^{27}$ Chela Sandoval, "New Sciences: Cyborg Feminism and the Methodology of the Oppressed," in The Cybercultures Reader, ed. David Bell and Barbara M. Kennedy (London: Routledge, 2000), 374-75.

${ }^{28}$ Ibid., 375.

${ }^{29}$ Ibid., 376-77.

${ }^{30}$ See Jann Pasler, "The Utility of Musical Instruments in the Racial and Colonial Agendas of Late Nineteenth-Century France," Journal of the Royal Musical Association 129/1 (2004): 24-76. 
Iyer cites Ronald Radano and Philip Bohlman's evocative assertion that "[a] specter lurks in the house of music, and it goes by the name of race."31

As one might expect, these lacunae expand at the Elegban junction of race and technology. Thus for a new generation of black electronic musicians, music became a way to push and challenge the economic, geographic, and informational boundaries of any and all "ghettoes" - and at least in the ghetto where I grew up, the trope of the "electronic nigger" (the title of a series of plays by the influential black playwright Ed Bullins) was hardly a complimentary one. The title character in the Bullins plays, for example, is a technologically facile buffoon and all-around Uncle Tom. ${ }^{32}$ The negative trope of the technology-blackness opposition recurs in poet Michael S. Harper's 1973 poem "In the Projects," in which the protagonist is a depressed Vietnam veteran, estranged by dint of his war experiences from his fellows on the basketball court:

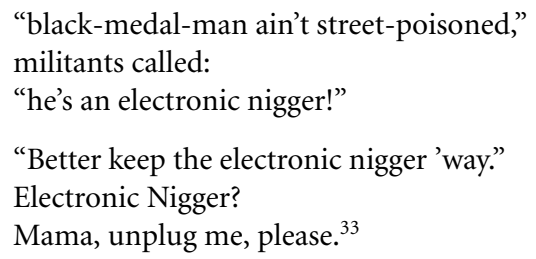

In contrast, the cover of a 1968 album by saxophonist Eddie Harris, featuring his broad, smiling visage positioned comfortably behind an electronic music device to which his horn is connected, laughingly invites the listener to "Plug Me In." The title of Harris's subsequent live album, released in 1969, a year before Miles Davis's Bitches Brew, warns of "High Voltage." ${ }^{34}$ Around 1965, Harris had become one of the first musicians in any field to seriously experiment, in concert and on records, with the new real-time music technologies, forging a trenchant connection between advanced electronic music techniques, extended acoustic instrumental technique, and down-home funk.

At heart, Harris was what the Germans call a Bastler, creating self-published, difficult-to-play books of technique and fashioning reed mouthpieces for trumpets, which he used in recordings and performances. Anticipating Miles Davis by at least two years, Harris used electric pianos and organs, and recorded pieces with realtime electronic sound processors such as the Varitone, a so-called octave divider that synthesized parallel octaves above or below the pitch of a horn, and the Echoplex,

\footnotetext{
${ }^{31}$ Ronald Radano and Philip V. Bohlman, "Introduction: Music and Race, Their Past, Their Presence," in Music and the Racial Imagination, ed. Ronald Radano and Philip V. Bohlman (Chicago: University of Chicago Press, 2000), 1.

${ }^{32}$ For an analysis of Bullins's play, see Leslie Catherine Sanders, The Development of Black Theater in America: From Shadows to Selves (Baton Rouge: Louisiana State University Press, 1989).

${ }^{33}$ Michael S. Harper, Images of Kin: New and Selected Poems (Urbana: University of Illinois Press, 1977), 101.

${ }^{34}$ Miles Davis, Bitches Brew, Columbia G2K 40577 (2 CDs), [1970] 1986; Eddie Harris, High Voltage, Atlantic SD-1529, 1969; and Harris, Plug Me In, Atlantic SD-1506, 1968.
} 
an early tape-based delay line noted for its portability. ${ }^{35}$ It is not known whether Davis and Harris ever discussed electronics - or for that matter, science fiction, with which neither artist was particularly associated-but Davis was undoubtedly aware of Harris's work, not only because Harris was quite prominent himself, but also because Davis recorded the saxophonist's now-canonical piece, "Freedom Jazz Dance" on his 1967 album, Miles Smiles. ${ }^{36}$

Certainly, this special issue on Technology and Black Music in the Americas would be incomplete without an audience with Sun Ra, who has inspired (and perhaps sired) more Afrofuturist paeans than any musician except George Clinton-perhaps a holdover from the days when jazz was said to divine the future, or a yearning for the Ethiopianist Zion that Ra and so many others in the black diaspora have evoked. Brent Hayes Edwards's review here of The Wisdom of Sun Ra (edited by John Corbett) cites a 1986 interview in which Ra saxophonist John Gilmore claims that the Nation of Islam had drawn from Ra's views. Gilmore's sense of Ra as originary, however, leaves very little space for the dynamics unearthed by historian Daniel Widener, who identifies an Asian presence in Afrofuturism:

\begin{abstract}
Elusive Asian radicals spread a message of apocalyptic racial revolt throughout the United States' internal colonies which survives, in various guises, into the present day. While the membership rolls of the Society for the Development of Our Own, the Pacific Movement of the Eastern World, and the Moorish Science Temple contained but a miniscule fraction of black America, the message of Japanese deliverance spread by W. D. Fard, Satohata Takahashi, and Policarpio Manansala achieved a wide consonance in African American life. Spreading an impassioned missive complete with Japanese bombers, troops, and arms, these figures and groups attracted thousands of blacks searching for a swift end to a seemingly intractable racism. The proponents of this vision often sought to tie African Americans and Asians together biologically, and the vision of Japanese "motherships," the language of the "Asiatic Black Man," and the fiery destruction of a racist white world proved enduring. However fanciful such scenarios might be, they remain important both as precursors to the explosion of a technophilic Afro-futurism in the 1970s and as a profound instance of the social construction of race from below. ${ }^{37}$
\end{abstract}

Widener's reference to W. D. Fard is worth further consideration here. Elijah Muhammad, founder of the Nation of Islam (born Elijah Poole in 1897), met Fard in Detroit in 1931. In the Nation's belief system, Fard becomes "Master Farad Muhammad" or "God in person," and in books such as Message to the Blackman, Elijah Muhammad credits Fard's 1930s teachings on the vision of Ezekiel's wheel as foundational to the Nation's belief in the "Mother Plane," a technologically advanced artificial planet whose capabilities are eventually deployed in an Armageddon that ensures the ultimate triumph of the black race over its enemies. According to Michael Lieb, technology-based interpretations of Ezekiel date from the Miltonic era, and the Nation's proto-Afrofuturist eschatology, which antedates Scientology's

${ }^{35}$ By his own account, Harris was also an early user of Robert Moog's new voltage-controlled synthesizers. During intermission at one of Harris's concerts at the New Morning jazz club in Paris in the 1980s, Harris proudly showed me his latest Moog-designed device.

${ }^{36}$ Miles Davis, Miles Smiles, Columbia CL 2601, 1967.

${ }^{37}$ Daniel Widener, "Perhaps the Japanese Are to Be Thanked?': Asia, Asian Americans, and the Construction of Black California,” positions 11/1 (Spring 2003): 26. 
more widely known futurisms by several decades, appears to date from around the same period when Gilmore was a toddler and Sun Ra was living in Birmingham, Alabama, in the Earthly guise of a teenager named Herman Blount. ${ }^{38}$

In this light, it seems evident that engaging multiracialism would be useful in theorizing the black musical encounter with technology. To begin with an energizing binary, on the one hand, we have Miles Davis, whose early forays into electronics, as Paul Tingen notes, were fostered as part of a multiracial, integrationist milieu encompassing jazz, rock, and classical musicians, as well as anyone else seeking the hybridities and fusions that were part of a general eclecticism in 1960s popular music making that entered the American classical world only grudgingly, as critic John Rockwell notes in his unjustly neglected 1983 book, All American Music. ${ }^{39}$

On the other hand, we have Eddie Harris, whose electronically vocalized saxophone on "Listen Here," recorded in early 1967, was enormously popular nationally, particularly in black communities around the United States, if less so in the white communities that embraced Davis's new electronic music. ${ }^{40}$ Imprudently, in 1970 Harris attacked Davis publicly for fostering a "new white image"-ironically, a charge that was soon leveled at Harris himself. ${ }^{41}$ The remark needs to be contextualized by noting that Harris cut his musical teeth as Sun Ra did, in the 100\% hypersegregated, overcrowded, cheek-by-jowl black environment of Chicago's South Side, where Ra's claim of extraterrestriality could be seen as having the effect (and perhaps even a playfully Signifying intent) of hiding any histories of his work (including its pre-1961 reliance on twelve-bar blues and AABA forms) that were not audible to the more sound-challenged critics.

That such all-black, largely working-class environments could become the staging ground for eclectic fusions and postmodernities need not surprise us- that is, if we recognize that it was not hybridity but mobility, the master trope of the Great

\footnotetext{
${ }^{38}$ In 1989, Louis Farrakhan, Elijah Muhammad's self-proclaimed successor, recounted his own abduction by aliens from the Mother Wheel. See Mattias Gardell, In the Name of Elijah Muhammad: Louis Farrakhan and the Nation of Islam (Durham, N.C.: Duke University Press, 1996). For a detailed history of the technological interpretation of Ezekiel, including the Nation of Islam's visions, see Michael Lieb, Children of Ezekiel: Aliens, UFOs, the Crisis of Race, and the Advent of End Time (Durham, N.C.: Duke University Press, 1998).

${ }^{39}$ See Paul Tingen, Miles Beyond: The Electric Explorations of Miles Davis, 1967-1991 (New York: Billboard Books, 2003). John Rockwell, All American Music: Composition in the Late Twentieth Century (New York: Da Capo Press, [1983] 1997). Rockwell's ideas have now entered the mainstream of US cultural programming, even if one signal attempt to put his ideas into practice as director of the Lincoln Center Festival was roundly condemned by New York critics when he selected Ornette Coleman as 1997's composer-in-residence. His rejoinder is noteworthy: "Most disturbingly, [Paul] Griffiths suggests that the idea of 'retrospectives devoted to the music of major American composers' might be 'worth reviving.' Curiously, from the exact opposite position in musical polemics, Kyle Gann of The Village Voice similarly suggested that this year we had 'nearly bailed out of the new music business.' Have either of these gentlemen heard of Ornette Coleman?" John Rockwell, letter to the editor, "New and Old Music Put in Context," New York Times, 17 August 1997.

${ }^{40}$ Eddie Harris, The Electrifying Eddie Harris, Atlantic SD-1495, 1968.

${ }^{41}$ Quoted in Ian Carr, Miles Davis: The Definitive Biography (New York: Thunder's Mouth Press, 1999), 285. For an account of the black nationalist criticism of Davis and Harris, see George E. Lewis, “The Virtual Discourses of Pamela Z," Journal of the Society for American Music 1/1 (February 2007): $57-78$.
} 
Migration, that fueled the aspirations of black people in a complexly articulated but socially black milieu like the South Side, which had a larger population of African descent in 1960 than all of Great Britain did in 2001. ${ }^{42}$ In this light, Birmingham School theorizations of hybridity could be viewed as the recognition of a hopeful post-race reality, but also as a metaphorization of multiracial political coalition, a minoritarian response to local conditions.

"Strategic" hybridity, however, is hardly generalizable to a complex diaspora. Local conditions do matter, and in a globalized environment, paradoxically, they matter more than ever. Thus, techno founder Juan Atkins's phaneric deployment of the mask of "Model 500" not only avoids racial typing but also asserts mobility in a way that, in Houston Baker's words, "secures territorial advantage and heightens a group's survival possibilities." 43 Here, we need to remember that this kind of experimentalism can take many forms, draw from many histories, confront different methodological challenges, and manifest a self-awareness as being in dialogue with the music of the whole earth—all while emerging from a black environment.

Having spent this entire essay discussing Afrofuturist production, I'd like the reader to spend a few moments after its conclusion considering modes of Afrofuturist listening, consumption, and dissemination, matters that I won't have space to discuss here. While those notions reverberate, let us make a brief foray into the troubled history that black musicians have had with labels and labeling. As Duke Ellington remarked in 1962, in the wake of decades spent evading racialized categories, "Let's not worry about whether the result is jazz or this or that type of performance. Let's just say that what we're all trying to create, in one way or another, is music." ${ }^{\prime 4}$ In contrast, Leroy Jenkins, speaking in 1997, maintained that "I don't mind the labels; they can put the labels one right after the other if it will get me work. But then, on the other hand, if it's going to keep me from getting work, I don't want to be put in that position." 45

But one reform I am not calling for is the "expansion" of the label "Afrofuturism" to perform a wider range of cultural work. As Ellington realized, there is more at stake in these label disputes than simple, immediate pragmatics. As a tool by which sociomusical networks produce what counts as knowledge and repair border breaches, labels themselves tend towards hegemonies that reduce mobility and clog communication lines. Dizzy Gillespie's account of a conversation with the Duke, quoted by Eric Porter, presents the issue well by way of conclusion:

${ }^{42}$ I draw here upon the ideas on the post-slavery deployment of power through movement articulated in Farah Jasmine Griffin, "Who Set You Flowin'?": The African-American Migration Narrative (New York: Oxford University Press, 1995).

${ }^{43}$ Houston A. Baker, Modernism and the Harlem Renaissance (Chicago: University of Chicago Press, 1989), 51.

${ }^{44}$ Duke Ellington, “Ellington: Where Is Jazz Going? (1962),” in The Duke Ellington Reader, ed. Mark Tucker (New York: Oxford University Press, 1993), 326.

${ }^{45}$ Ludwig Van Trikt, “Leroy Jenkins,” Cadence, November 1997, 6. 
In the context of the economics of the industry and the racial discourse surrounding the music, the label [bebop] had the power to fix a complicated series of musical innovations in a particular time and place and make them irrelevant. Gillespie recalled that Ellington warned him about the problems with categories: "Duke Ellington once told me: 'Dizzy, the biggest mistake you made was to let them name your music bebop, because from the time they name something, it is dated.' "46

\section{References}

Baker, Houston A. Modernism and the Harlem Renaissance. Chicago: University of Chicago Press, 1989.

Carr, Ian. Miles Davis: The Definitive Biography. New York: Thunder's Mouth Press, 1999.

Césaire, Aimé. Cahier d'un retour au pays natal. 2nd edn. Ed. with introduction, commentary, and notes by Abiola Irele. Columbus: Ohio State University Press, [1939] 2000.

- Notebook of a Return to the Native Land. Trans. and ed. Clayton Eshleman and Annette Smith. Middletown, Conn.: Wesleyan University Press, [1939] 2001.

Craft, Morgan. "Towards a New Consciousness" (letter to the editor). The Wire, October 2005, 8.

Dery, Mark. "Black to the Future: Interviews with Samuel R. Delany, Greg Tate, and Tricia Rose." In Flame Wars: The Discourse of Cyberculture, ed. Mark Dery, 179-222. Durham, N.C.: Duke University Press, 1994.

Diop, Cheikh Anta. The Cultural Unity of Black Africa: The Domains of Patriarchy and of Matriarchy in Classical Antiquity. Chicago: Third World Press, 1978.

Ellington, Duke. "Ellington: Where Is Jazz Going?" In The Duke Ellington Reader, ed. Mark Tucker, 324-25. New York: Oxford University Press, [1962] 1993.

Eshun, Kodwo. More Brilliant Than the Sun: Adventures in Sonic Fiction. London: Quartet Books, 1998.

Everett, Anna, and Amber J. Wallace, eds. AfroGEEKS: Beyond the Digital Divide. Santa Barbara, Calif.: Center for Black Studies Research, 2007.

Gardell, Mattias. In the Name of Elijah Muhammad: Louis Farrakhan and the Nation of Islam. Durham, N.C.: Duke University Press, 1996.

Griffin, Farah Jasmine. "Who Set You Flowin'?": The African-American Migration Narrative. New York: Oxford University Press, 1995.

Harper, Michael S. Images of Kin: New and Selected Poems. Urbana: University of Illinois Press, 1977.

Harrison, Max, Charles Fox, and Eric Thacker. The Essential Jazz Records. Vol. 2, Modernism to Postmodernism. London: Continuum International Publishing Group, 2000.

Kantrowitz, Barbara, et al. "A is for Ashanti, B is for Black.” Newsweek, 23 September 1991.

${ }^{46}$ Eric Porter, What Is This Thing Called Jazz? African American Musicians as Artists, Critics, and Activists (Berkeley: University of California Press, 2002), 99. 
Lessing, Doris. The Sirian Experiments: The Report by Ambien II, of the Five. New York: Vintage Books, 1982.

Lewis, George E. “The Virtual Discourses of Pamela Z." Journal of the Society for American Music 1/1 (February 2007): 57-78.

Lieb, Michael. Children of Ezekiel: Aliens, UFOs, the Crisis of Race, and the Advent of End Time. Durham, N.C.: Duke University Press, 1998.

Lovink, Geert. "'Everything was to be done. All the adventures are still there': A Speculative Dialogue with Kodwo Eshun.” 2000. Telepolis website, http://www. heise.de/tp/r4/artikel/6/6902/1.html.

Mailer, Norman. Existential Errands. New York: New American Library, 1973.

Miller, Paul D. "Afro-Futurism: A Statement of Intentions-Outside In, Inside Out." 2002. Afrofuturism website, http://www.afrofuturism.net/text/Manifestos/ Miller01.html.

Nelson, Alondra. "Introduction: Future Texts." Social Text 20/2 (Summer 2002): $1-15$.

“New Performance Interfaces 2.” Computer Music Journal 14/2 (Summer 1990): 87-97.

Pasler, Jann. "The Utility of Musical Instruments in the Racial and Colonial Agendas of Late Nineteenth-Century France." Journal of the Royal Musical Association 129/1 (2004): 24-76.

- Writing Through Music: Essays on Music, Culture, and Politics. New York: Oxford University Press, 2008.

Porter, Eric. What Is This Thing Called Jazz? African American Musicians as Artists, Critics, and Activists. Berkeley: University of California Press, 2002.

Puckette, Miller. "Languages and Environments for Computer Music: Max at Seventeen.” Computer Music Journal 26/4 (2002): 31-43.

Radano, Ronald, and Philip V. Bohlman. "Introduction: Music and Race, Their Past, Their Presence." In Music and the Racial Imagination, ed. Ronald Radano and Philip V. Bohlman, 1-56. Chicago: University of Chicago Press, 2000.

Rockeymoore, Mark A. "What Is Afrofuturism?" 2002. AuthorsDen website, http://www.authorsden.com/visit/viewarticle.asp?AuthorID=7174\&id=4308.

Rockwell, John. All American Music: Composition in the Late Twentieth Century. New York: Da Capo Press, [1983] 1997.

"New and Old Music Put in Context" (letter to the editor). New York Times, 17 August 1997.

Sanders, Leslie Catherine. The Development of Black Theater in America: From Shadows to Selves. Baton Rouge: Louisiana State University Press, 1989.

Sandoval, Chela. "New Sciences: Cyborg Feminism and the Methodology of the Oppressed." In The Cybercultures Reader, ed. David Bell and Barbara M. Kennedy, 374-90. London: Routledge, 2000.

Schwanauer, Stephan M., and David A. Levitt. Machine Models of Music. Cambridge, Mass.: MIT Press, 1993.

Seachrist, Denise E. The Musical World of Halim El-Dabh. Kent, Ohio: Kent State University Press, 2003. 
Stanyek, Jason. "Transmissions of an Interculture: Pan-African Jazz and Intercultural Improvisation." In The Other Side of Nowhere: Jazz, Improvisation, and Communities in Dialogue, ed. Daniel Fischlin and Ajay Heble, 87-130. Middletown, Conn.: Wesleyan University Press, 2004.

Tingen, Paul. Miles Beyond: The Electric Explorations of Miles Davis, 1967-1991. New York: Billboard Books, 2003.

Van Trikt, Ludwig. "Leroy Jenkins." Cadence, November 1997, 5-9.

Veal, Michael E. Dub: Soundscapes \& Shattered Songs in Jamaican Reggae. Middletown, Conn.: Wesleyan University Press, 2007.

Wallace, Michele. Black Macho and the Myth of the Superwoman. London: Verso, [1978] 1999.

Weheliye, Alexander G. “'Feenin': Posthuman Voices In Contemporary Black Popular Music." Social Text 20/2 (Summer 2002): 21-47.

Widener, Daniel. "'Perhaps the Japanese Are to Be Thanked?': Asia, Asian Americans, and the Construction of Black California." positions 11/1 (2003): 135-81.

Yavelow, Christopher. "A Report on the Workshop for Music Notation by Computer." Computer Music Journal 11/2 (Summer 1987): 65-70.

\section{Discography}

Davis, Miles. Bitches Brew. Columbia G2K 40577 (2 CDs), 1970.

. Miles Smiles. Columbia CL 2601, 1967.

El-Dabh, Halim. Crossing Into the Electric Magnetic. Without Fear Recordings, 2001. Harris, Eddie. The Electrifying Eddie Harris. Atlantic SD-1495, 1968.

- High Voltage. Atlantic SD-1529, 1969.

- Plug Me In. Atlantic SD-1506, 1968. 